\title{
Lessons learnt from outstanding mid-career women in endocrine cancer research
}

\author{
Deborah J Marsh' and Charis Eng',3,4 \\ ${ }^{1}$ Hormones and Cancer Group, Kolling Institute of Medical Research, Royal North Shore Hospital, \\ University of Sydney, St Leonards, New South Wales, Australia \\ ${ }^{2}$ Genomic Medicine Institute, Cleveland Clinic, Cleveland, Ohio, USA \\ 3Deparment of Genetics and Genome Sciences, Case Western Reserve University School of Medicine, \\ Cleveland, Ohio, USA \\ ${ }^{4}$ Germline High Risk Focus Group, Comprehensive Cancer Center, Case Western Reserve University \\ School of Medicine, Cleveland, Ohio, USA
}

Correspondence should be addressed to D J Marsh Email deborah.marsh@sydney.edu.au
As cancer researchers, scientific data are by far the predominant language with which we tell our stories. We tell these stories in scientific publications, our conference presentations, to our trainees and to agencies and philanthropists supporting us to conduct fundamental basic and translational research. These stories are the path to achieving the ultimate goal of improving the lives of cancer patients. But to borrow from the American author Stephen King, 'I think the best stories always end up being about the people.' This thematic series highlighting midcareer women in endocrine cancer research presents some of these stories to acknowledge success, learn about new research fields and gain glimpses into the challenges, decision-making processes and roads travelled by these women on their path to achieving their professional goals.

To establish this series, endorsing societies of Endocrine-Related Cancer were contacted and the journal undertook a dedicated marketing campaign seeking nominations of outstanding mid-career women in endocrine cancer research. Nominees were assessed by a subset of editorial board members and the top six women from a competitive group were selected to be featured in this series, both through personal profiles and review articles of their current research areas. Review articles focus on a broad range of topics, including how molecularbased discoveries are beginning to drive new treatment strategies for neuroendocrine (NET) tumours (Pavel \& Sers 2016); aspects of understanding prostate cancer, including the role of DNA methylation (Sweet \& Ting 2016), the role of nuclear receptors (Leach et al. 2016) and circadian rhythmicity in the development and progression of this malignancy (Kiss \& Ghosh 2016); as well as the role of extracellular matrix proteins in ovarian cancer metastasis (Ricciardelli et al. 2016) and thyroid-stimulating hormone in thyroid cancer (Nieto \& Boelaert 2016).

In recent years, numerous articles have focussed on why there is a global underrepresentation of half of the world's population, i.e. women, especially at senior levels, in academic medical research (Muhlenbruch \& Jochimsen 2013, Shen 2013, Casadevall 2015, Ovseiko et al. 2016). Programs designed to address these issues, such as the Athena SWAN Charter in the UK (Donald et al. 2011) and the Asia-Pacific Economic Cooperation (APEC) and Women in STEM (Science, Technology, Engineering and Mathematics) study, are offering new guidelines with the goal of influencing these inequities. Younger researchers wishing to emulate the success spoken of in this series will no doubt be navigating a different landscape, dictated somewhat by the changing expectations driven by programs such as these. Still, much of the experience and wisdom of successful people are timeless, and although there is no single 'formula' to guarantee success as a medical researcher, a number of common threads have emerged from these stories. Some of these are discussed below.

\section{Early curiosity of science}

Scientists are frequently driven by keen powers of observation, a fascination of the natural world and the

This editorial accompanies a special section on Celebrating Women in Cancer Research. The Guest Editors for this section were Charis Eng and Deborah Marsh Downloaded from Bioscientifica.com at 04/26/2023 09:43:13AM 
need to understand and explain it. A number of women spoke of childhood fascination of nature - 'How could understanding how things work not be the most fascinating thing?' (Bevan 2016). Early interest in science was quite broad, with two women in this series beginning their training as physicists before ultimately working in biology (Bevan 2016, Ghosh 2016).

\section{The importance of strong academic mentors}

The influence and importance of mentors, both men and women, permeate the stories in this series and is perhaps the strongest theme running throughout - 'I appreciated finding kind and strong support along my way' (Pavel 2016). Academic mentors come in many different forms, from the most senior academics, leaders in their fields, who may recruit you and seek to nurture your potential, to those closer to your career stage. Mentors may be the ones who work with you at the bench, teaching you the techniques and strategies you need to learn to understand what is possible in medical research. They readily share their knowledge with you, perhaps suggesting areas of research that would benefit from your intellect and skills. Mentors may also provide the gentle nudge you need to apply for an opportunity such as a new position in another country or a large grant to fund your research. They have the power to shape all of our academic paths, including preparing us to step up and take on the mantle of mentor for early career researchers following in our own footsteps - 'Through dedicated and committed guidance by my mentors, I have learned to appreciate the importance of training the next generation of researchers and clinicians' (Boelaert 2016).

\section{Determination to overcome difficulties}

The comedically told story of trouble-shooting a difficult experiment in 'Dude, where's my band?' underscores the patience and focussed determination required to navigate what, at times, can feel like a minefield in the laboratory (Ting 2016). In fact, the concept of tenacity and determination is a firm undercurrent in all of these stories, with many expressing a 'strong determination to succeed and not give up when I found something difficult' (Ricciardelli 2016).

\section{The power of collaborations and networks}

Extended collaborations and networks, whether you are the creator of these networks or a participant within them, can be career-defining. There are many examples of collaborative initiatives in this series, with the importance of these networks for studying rare malignancies such as neuroendocrine tumours (NETs) made especially clear - 'Due to the rarity of the disease, large randomised controlled trials could only be initiated in an international setting' (Pavel 2016). Establishment of patient support groups is also discussed. Undoubtedly, the message is to participate in collaboration and networks; be the driver of these structures if they do not already exist, do this early and then whenever possible and appropriate in your career - 'As any sensible scientist should, I continue to call on my valued colleagues for input, collaboration and help on a regular basis' (Bevan 2016). Many spoke of the pleasure of establishing and/or working in teams of multidisciplinary clinically and scientifically trained researchers, this diversity of skills bringing strength to many research endeavours.

\section{On family, partners and children}

Women spoke warmly of the support from parents, both those who had come from academic families, and those who were the first in their families to enter into academia. The importance of parents, in many ways our first mentors, was recognised in fuelling an 'inquisitive spirit' and 'thirst for knowledge and discovery' (Boelaert 2016). It is not uncommon in academia to have an academic partner and stories include career decisions based on location, or relocation, of partners. With complete clarity and consistency, these potential forks in the road were viewed as opportunities for career advancement.

Career decisions made around children are discussed, from choosing to stop laboratory work temporarily during pregnancy, working part-time when children were young, and remaining geographically nearby to extended family during these early years for support. The overall message is that a successful career in medical research can be combined with raising a family if this is what you choose to do - 'Balancing family life and work was always a juggle but also very rewarding' (Ricciardelli 2016).

\section{Parting advice to those following in the footsteps}

Collectively, and with the benefit of hindsight built on years of experience, a number of clear messages emerge from the women in this series. Through all the swings and roundabouts that constitute a career in medical research, you will never stop learning. It is important to protect time 
for critical thinking, something that is well recognised as 'vitally important to the scientific process' (Ting 2016). Learn how to do this now, and it will serve you for the rest of your career. It is equally important to maintain the early curiosity that first set you on your scientific path and to nurture it in others. Whether your drivers are intellectual curiosity, a desire to help patients, or a mix of these things, keep your focus and remain tenacious in achieving your goals. Wherever possible, choose to 'work on what really excites you with people you like and respect' (Bevan 2016).

There are many more pearls of wisdom in the individual profiles in this series. Finally, remember to share your own stories with your colleagues, both women and men, and especially those aiming to follow in your footsteps. 'In the future, there will be no female leaders. There will just be leaders.' - Cheryl Sandberg, COO, Facebook, 2015.

\section{Declaration of interest}

The authors declare that there is no conflict of interest that could be perceived as prejudicing the impartiality of this editorial.

\section{Funding}

This work did not receive any specific grant from any funding agency in the public, commercial, or not-for-profit sector.

\section{References}

Bevan CL 2016 WOMEN IN CANCER PROFILE: A gender agenda. Endocrine-Related Cancer 23 P5-P8. (doi:10.1530/erc-16-0392)

Boelaert K 2016 WOMEN IN CANCER PROFILE: From bedside to bench and back: my journey in thyroid disease. Endocrine-Related Cancer 23 P9-P13. (doi:10.1530/erc-16-0396)

Casadevall A 2015 Achieving speaker gender equity at the American Society for Microbiology general meeting. MBio 6 e01146. (doi:10.1128/mbio.01146-15)
Donald A, Harvey PH \& McLean AR 2011 Athena SWAN awards: bridging the gender gap in UK science. Nature 47836. (doi:10.1038/478036b)

Ghosh PM 2016 WOMEN IN CANCER PROFILE: From physics to cancer biology and everywhere in between. Endocrine-Related Cancer 23 P15-P21. (doi:10.1530/erc-16-0382)

Kiss Z \& Ghosh PM 2016 WOMEN IN CANCER THEMATIC REVIEW: Circadian rhythmicity and the influence of 'clock' genes on prostate cancer. Endocrine-Related Cancer 23 T123-T134. (doi:10.1530/erc-16-0366)

Leach DA, Powell SM \& Bevan CL 2016 WOMEN IN CANCER THEMATIC REVIEW: New roles for nuclear receptors in prostate cancer. EndocrineRelated Cancer 23 T85-T108. (doi:10.1530/erc-16-0319)

Muhlenbruch B \& Jochimsen MA 2013 Research policy: only wholesale reform will bring equality. Nature 495 40-42. (doi:10.1038/495040a)

Nieto H \& Boelaert K 2016 WOMEN IN CANCER THEMATIC REVIEW: Thyroid stimulating hormone in thyroid cancer: does it matter? Endocrine-Related Cancer 23 T109-T121. (doi:10.1530/erc-16-0328)

Ovseiko PV, Edmunds LD, Pololi LH, Greenhalgh T, Kiparoglou V, Henderson LR, Williamson C, Grant J, Lord GM, Channon KM, et al. 2016 Markers of achievement for assessing and monitoring gender equity in translational research organisations: a rationale and study protocol. BMJ Open 6 e009022. (doi:10.1136/bmjopen-2015-009022)

Pavel ME 2016 WOMEN IN CANCER PROFILE: Neuroendocrine tumors: moving from the land of small tumors to an expanding universe. Endocrine-Related Cancer 23 P23-P26. (doi:10.1530/erc-16-0371)

Pavel ME \& Sers C 2016 WOMEN IN CANCER THEMATIC REVIEW: Systemic therapies in neuroendocrine tumors and novel approaches towards personalized medicine. Endocrine-Related Cancer $\mathbf{2 3}$ T135-T154. (doi:10.1530/ERC-16-0370)

Ricciardelli C 2016 WOMEN IN CANCER PROFILE: My pathway to understanding the role of the tumour microenvironment in cancer progression. Endocrine-Related Cancer 23 P27-P31. (doi:10.1530/erc16-0335)

Ricciardelli C, Lokman NA, Ween MP \& Oehler MK 2016 WOMEN IN CANCER THEMATIC REVIEW: Ovarian cancer-peritoneal cell interactions promote extracellular matrix processing. EndocrineRelated Cancer 23 T155-T168. (doi:10.1530/erc-16-0320)

Shen H 2013 Inequality quantified: mind the gender gap. Nature $\mathbf{4 9 5}$ 22-24. (doi:10.1038/495022a)

Sweet TJ \& Ting AH 2016 WOMEN IN CANCER THEMATIC REVIEW: Diverse functions of DNA methylation: implications for prostate cancer and beyond. Endocrine-Related Cancer 23 T169-T178. (doi:10.1530/erc-16-0306)

Ting AH 2016 WOMEN IN CANCER PROFILE: Dude, where's my band? Endocrine-Related Cancer 23 P33-P35. (doi:10.1530/erc-16-0387)

Received in final form 12 September 2016

Accepted 12 September 2016
(C) 2016 Society for Endocrinology Printed in Great Britain
Published by Bioscientifica Ltd 